\title{
Water Infiltration and Surface Runoff in Steep Clayey Soils of Olive Groves under Different Management Practices
}

\author{
Giuseppe Bombino ${ }^{1}$, Pietro Denisi ${ }^{1}$, Josè Alfonso Gómez ${ }^{2}$ (i) and Demetrio Antonio Zema ${ }^{1, *(1)}$ \\ 1 Department "Agraria”, Mediterranea University of Reggio Calabria, Località Feo di Vito, \\ 89122 Reggio Calabria, Italy; giuseppe.bombino@unirc.it (G.B.); pietro.denisi@unirc.it (P.D.) \\ 2 Agronomy Department, Institute for Sustainable Agriculture (IAS-CSIC), Avenida Menendez Pidal s/n, \\ E-14004 Córdoba, Spain; joseagomez@ias.csic.es \\ * Correspondence: dzema@unirc.it; Tel.: +39-0965-1694-295
}

Received: 28 December 2018; Accepted: 29 January 2019; Published: 31 January 2019

\begin{abstract}
When olive groves are cultivated on clayey soils with steep gradients, as in many Mediterranean areas, reducing the runoff and soil erosion rates by adopting proper soil management practices is imperative. A soil cover by pruning residues may represent an alternative to the commonly adopted mechanical tillage. This study evaluates the water infiltration rates and surface runoff volumes in a steep and clayey olive grove of Southern Italy. These hydrological variables are measured at the plot scale under four soil management practices (mechanical tillage, total artificial protection of soil and soil cover with two different rates of vegetal residues). The measurements have been carried out using a rainfall simulator under dry (undisturbed) and wet (that is, on soils disturbed by intense rainfall) conditions. The mechanical tillage leads to lower water infiltration rates and higher runoff production. The retention of a soil cover by vegetal residues (in the range $3.5-17.5$ tons / ha of dry matter) reduces the runoff rate on average by $30 \%$, mainly because of the increased soil infiltration rates (over 100\%, compared to mechanical tillage). After soil disturbance due to antecedent rainfall, the runoff generation capacity of a soil disturbed by a heavy precipitation significantly increased compared to undisturbed soils because of the decrease in soil infiltration rates. Overall, the retention of vegetal residues over the soil may be advisable to reduce surface runoff generation rates, particularly for saturated soils.
\end{abstract}

Keywords: soil management; surface runoff; pruning residues; soil loss; water infiltration; olive groves; cover crops

\section{Introduction}

In many areas of the Mediterranean basin, olive growing is performed on sloping areas, often on steep gradients, where other crops are not able to grow. Thanks to its low water requirement, an olive tree has the capacity to grow in hilly areas, where irrigation cannot be practised.

Although in recent decades, olive cultivation tended to be practiced in flat lands, in the Calabria region of Southern Italy, many hectares of olive groves are still located in sloping areas. Here, the semi-arid climate makes these lands prone to high runoff and soil erosion; this affects olive productivity as a result of the reduced soil capacity to store water [1-4]. Moreover, when olive groves are cultivated on soils with a high clay content (where the combination of slope and texture makes it more difficult or impossible other crops to grow), the low infiltration capacity of soils dominated by the "infiltration-excess" for runoff generation mechanisms may increase the runoff and erosion rates [5]. Therefore, the importance of a good infiltration capacity of soil is clear. This can be 
achieved by adopting suitable soil management techniques. The higher the infiltration, the higher the water availability for crops, which is desirable in semi-arid environment characterised by chronic water shortage.

In Mediterranean olive groves, mechanical tillage still represents the most common practice for soil management [6-9], since it temporarily improves rainfall infiltration and water distribution in the soil profile, destroys weeds, reduces fire danger and incorporates fertilizers into the soil $[8,10]$. However, this practice over time may also result in degradation of the soil structure, which can reduce water infiltration rate, accelerating runoff and erosion processes and reducing water availability in the rhizosphere; moreover, mechanical tillage may compact excessively the soil and sometimes result in a loss of nutrients, fertilizer and organic matter. Thus, in Mediterranean orchards, there is the need for sustainable agronomical practices (that is, soil management models, which are alternatives to mechanical tillage), combining the contrasting requirements of soil and water conservation, maintaining or increasing, at the same time, crop production [11]. These contrasting goals can be achieved by "Conservation Agriculture" [12], which suggests a set of crop cultivation techniques based mostly on increasing ground cover, integrating the protection of soil, water and biological resources with crop requirements.

One of the most suitable soil conservation models for Mediterranean fruit orchards (thus, for olive groves as well) is the application of organic materials [13], aiming to retain vegetal biomass (usually crop residues) on the soil surface in combination with a cover of herbaceous plants [14]. Applying a vegetal cover by crops or residues increases the content of organic matter in the soil, which is highly advantageous for fertility and biodiversity [13]. Many experimental works have demonstrated that the use of a vegetal cover during fall and winter can reduce soil loss to tolerable rates compared with bare soil, e.g., [3,8], while simultaneously also having beneficial effects on biodiversity and maximizing ecosystem services [9]. For instance, Francia et al. [15] reported a reduction of more than $80 \%$ of soil loss using vegetal cover in plots with olive trees with a slope of $30 \%$. Ordoñez et al. [16] found that biomass retention on soil reduced erosion in organic olive groves by $56 \%$ compared to conventionally cultivated soil. Snelder and Bryan [17], investigating the relationship between ground cover values and soil loss under simulated rainstorms, found a critical threshold of $55 \%$ of vegetal ground cover, below which erosion rates rapidly increased. Monteiro and Lopes [18] and Francia et al. [19] recommended cover crops in both vineyards and olive groves in Mediterranean areas to improve soil and water conservation. Although the benefits of cover crop and biomass retention are known and justified (e.g., [12,19]), many farmers are still hesitant to apply this practice; they perceive that crop cover (i) makes cultivation and harvesting operations more difficult, (ii) increases the risk of water competition between olive and other weed, (iii) increases the management costs and (iv) leads to a possible yield reduction [9].

A proper vegetal cover shields soil from raindrop impact (avoiding particle detachment due to splash erosion) and increases infiltration, reducing sealing of the soil surface $[8,12,15,20,21]$. Many studies have been carried out on the effects of cover crops on soil properties (e.g., [1,22-27]). All these studies suggest the need for reducing soil erosion rates in olive orchards, increasing ground cover, using either cover crops or mulches [9]. The benefits of a ground cover for soil conservation and its water balance improvement are linked to the presence of vegetal residues, maintaining a dense cover over the soil for the longest possible time [13]. However, less attention has been paid to soil management, and very few studies have been published about the effect of pruning residues on the hydrological response in olive groves over steep slope areas at the plot scale, e.g., [13,28]. Under these climatic and pedological conditions, the improvement of water infiltration in olive groves with low soil permeability and high slope is imperative to reduce runoff generation, soil erosion rates and nutrient mobilization [29].

To fill this gap, this study aims to evaluate the water infiltration rates of top soil and surface runoff volumes measured at the plot scale in a steep and clayey olive grove of Southern Italy under four soil management practices (hereafter SMPs). More specifically, of these practices, one represents 
the ideal soil conservation model, the second is mechanical tillage (the most common practice locally adopted), while two other models are related to soil cover with two different doses of vegetal residues from pruning residues. The measurements of infiltration and surface runoff were carried out using a rainfall simulator and under dry (not disturbed soil) and wet (that is, on soils disturbed by intense rainfall prior to infiltration measurement) conditions. This latter condition allowed the evaluation of the effects of rainfall disturbance on the soil hydrological response, since antecedent precipitation can induce soil saturation and sealing, which may enhance runoff generation. It is hoped that this study provides insights on how soil infiltration can be increased by applying pruning residues in a rate similar to the amount produced by an orchard under experimental field conditions.

\section{Materials and Methods}

\subsection{Experimental Site and Design}

The experimental site was an olive grove located on a farm close to the municipality of Locri $\left(38.2671^{\circ} \mathrm{N}, 16.1872^{\circ} \mathrm{E}\right.$, mean altitude of $114 \mathrm{~m}$ above sea level, Southern Calabria, Italy) (Figure 1a). The grove, with a slope of about 20\%, was planted about 10-12 years ago with olive trees (Olea europea, cultivar Geracese) at a $6 \times 6 \mathrm{~m}^{2}$ spacing (Figure $1 \mathrm{~b}$ ).

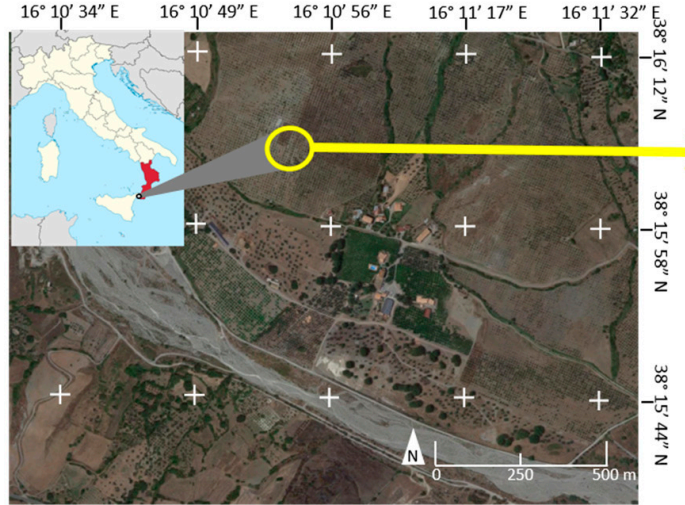

a)

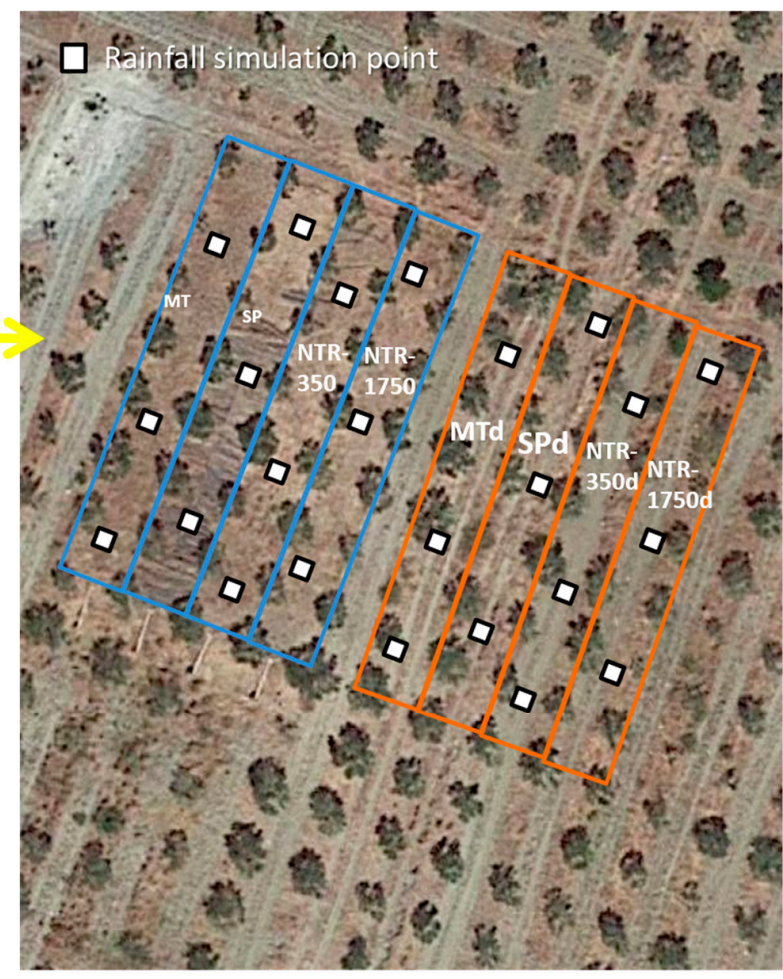

b)

Figure 1. Location (a) and aerial view (b) of the experimental plots (Locri, Southern Italy). Soil Management Practices (SMP): SP = Standard Protection of soil by a sheet; MT = Mechanical Tillage; NTR-350 = No Tillage and Retention of vegetal residues at a dry matter dose of 3.5 tons/ha; NTR-1750 = No Tillage and Retention of vegetal residues at a dry matter dose of 17.5 tons $/$ ha); the letter " $\mathrm{d}$ " refers to plots under disturbed conditions due to rainfall simulations.

The climate of the area is typical of the Mediterranean semi-arid environment, with mild, rainy winters and warm, dry summers, belonging to the "Csa" class ("Hot-summer Mediterranean" climate, according to Koppen [30]). The average annual rainfall is $1362 \mathrm{~mm}$ and the average annual temperature ranges from 11 to $27.5^{\circ} \mathrm{C}$ (historical observations of 1923-2017). The soil of the olive grove is Eutric cambisol [31], prevalently clayey with $28 \%(w / w)$ sand, $28 \%$ silt and $44 \%$ clay and a lack of soil 
skeletons. The soil depth is about $80 \mathrm{~cm}$ across all horizons (Ap, Bw1 and Bw2), rich in clay and silt; the impervious layer, parallel to the ground surface, is about $100 \mathrm{~cm}$ deep.

At the experimental site, eight $252-\mathrm{m}^{2}$ plots (each one $42-\mathrm{m}$-long and 6-m-wide) were identified; hydrological monitoring was carried out after simulating rainfall events (Figure 1b). Four plots were subjected to the following SMPs (Figure 2):

1. Standard Protection of soil, covering the plot by a horizontal sheet (mesh of $1 \mathrm{~mm}^{2}$ ), placed $10 \mathrm{~cm}$ over the ground (hereafter this practice will be indicated as "SP" and assumed as the control and reference practice);

2. Mechanical Tillage in autumn and spring by a rotary tiller (hereafter "MT");

3. No Tillage and Retention of vegetal residues at dry matter dose of 3.5 tons $/ \mathrm{ha}\left(350 \mathrm{~g} / \mathrm{m}^{2}\right.$, "NTR-350");

4. The same SMP as point 3, but with the dose of vegetal residues increased to 17.5 tons/ha of dry matter $\left(1750 \mathrm{~g} / \mathrm{m}^{2}\right.$, “NTR-1750”).

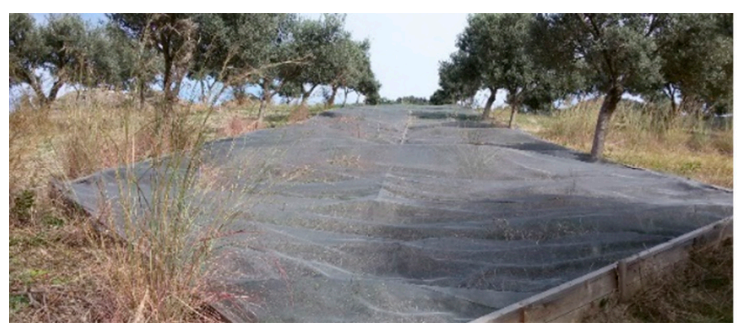

(a)

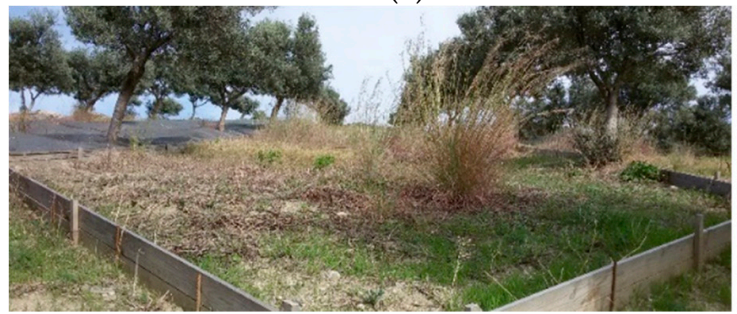

(c)

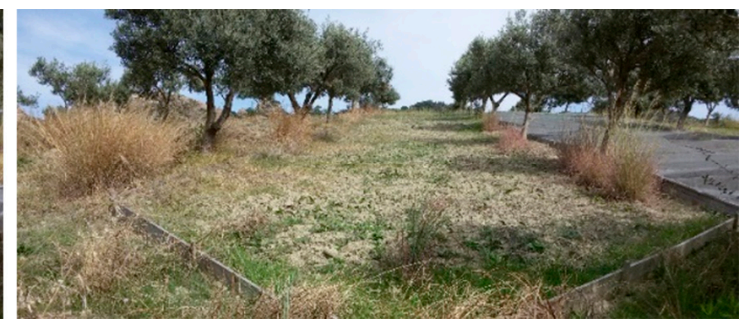

(b)

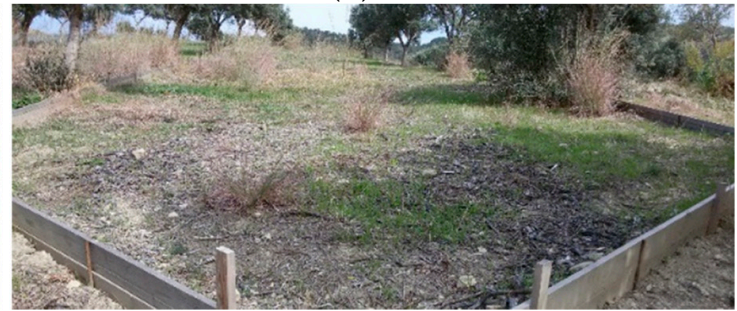

(d)

Figure 2. Views of the experimental plots subjected to the four SMPs (Locri, Southern Italy). Soil Management Practices (SMP): SP = Standard Protection of soil by a sheet (a); MT = Mechanical Tillage (b); NTR-350 = No Tillage and Retention of vegetal residues at a dry matter dose of.5 tons/ha (c); NTR-1750 = No Tillage and Retention of vegetal residues at a dry matter dose of 17.5 tons/ha) (d).

Under the SMPs No. 3 and 4, the vegetal residues (mean size 2 to $56 \mathrm{~cm}$ ), evenly distributed on the plots as mulching cover, were produced by chopping olive pruning residues (small branches and leaves) in spring (early April) and cutting weeds by a trimmer in spring and autumn.

"SP" represents an ideal (and theoretical) SMP, since the sheet with a small mesh size protects the soil from direct raindrop impact (thus greatly reducing the rainfall energy) and retains part of the precipitation (such as an ideal tree canopy with total soil cover), which evaporates. "MT" is the most common SMP adopted by the local farmers; under this practice, high soil losses in olive groves are noticed, with non-tolerable on-site and off-site problems. Therefore, the placement of vegetal residues on soil (modelled in "NTR-350" and "NTR-1750" plots) may be an advisable soil protection practice.

Furthermore, in order to evaluate the effects of rainfall disturbance on the soil hydrological response, the four SMPs were replicated in other four plots, previously subjected to simulated rainfall; hereafter, each SMP under disturbed conditions will be identified by the index " $\mathrm{d}$ " after the SMP acronym (for instance, "NTR-350d" is the plot mulched with 3.5 tons/ha of vegetal residues and subjected to simulated rainfall). 


\subsection{Hydrological Measurements and Analysis}

The Eijelkamp ${ }^{\circledR}$ rain simulator (hereafter "RS") was applied [32,33], simulating 3 rainfall events at the top, middle, and bottom of each eight-experimental plot (Figure 3). Before its use, RS was calibrated to produce $25 \mathrm{~mm}$-deep rainfall with a constant intensity of $50 \mathrm{~mm} / \mathrm{h}$ for $30 \mathrm{~min}$ and a specific kinetic energy of $121 \mathrm{~J} /\left(\mathrm{m}^{2} \cdot \mathrm{mm}\right)$ over an area of $0.25 \mathrm{~m}^{2}$. This rainfall intensity is typical of erosive events occurring in this area every $30-50$ years (this return interval was estimated by statistically processing an 80-year historical rainfall series, collected in nearby rain gauge stations). During the simulations, the surface runoff volume was collected on a time scale of minutes; time to peak (hereafter " $\mathrm{T}_{\mathrm{p}}$ "), peak runoff (" $\mathrm{Q}_{\mathrm{p}}$ ") and cumulative surface runoff ("SR") volume were measured. More specifically, " $\mathrm{T}_{\mathrm{p}}$ " was the time that elapsed from the measurement start to " $\mathrm{Q}_{\mathrm{p}}$ " occurrence; " $\mathrm{Q}_{\mathrm{p}}$ " was the maximum runoff volume; "SR" was the integral in time of " $\mathrm{Q}_{\mathrm{p}}$ ". In addition, the mean infiltration rate ("IR") was estimated, subtracting the measured runoff from the simulated rainfall and relating this water volume to the time elapsed from the measurement start. All measurements (in triplicate for each treatment) were carried out in the lane area during the spring.
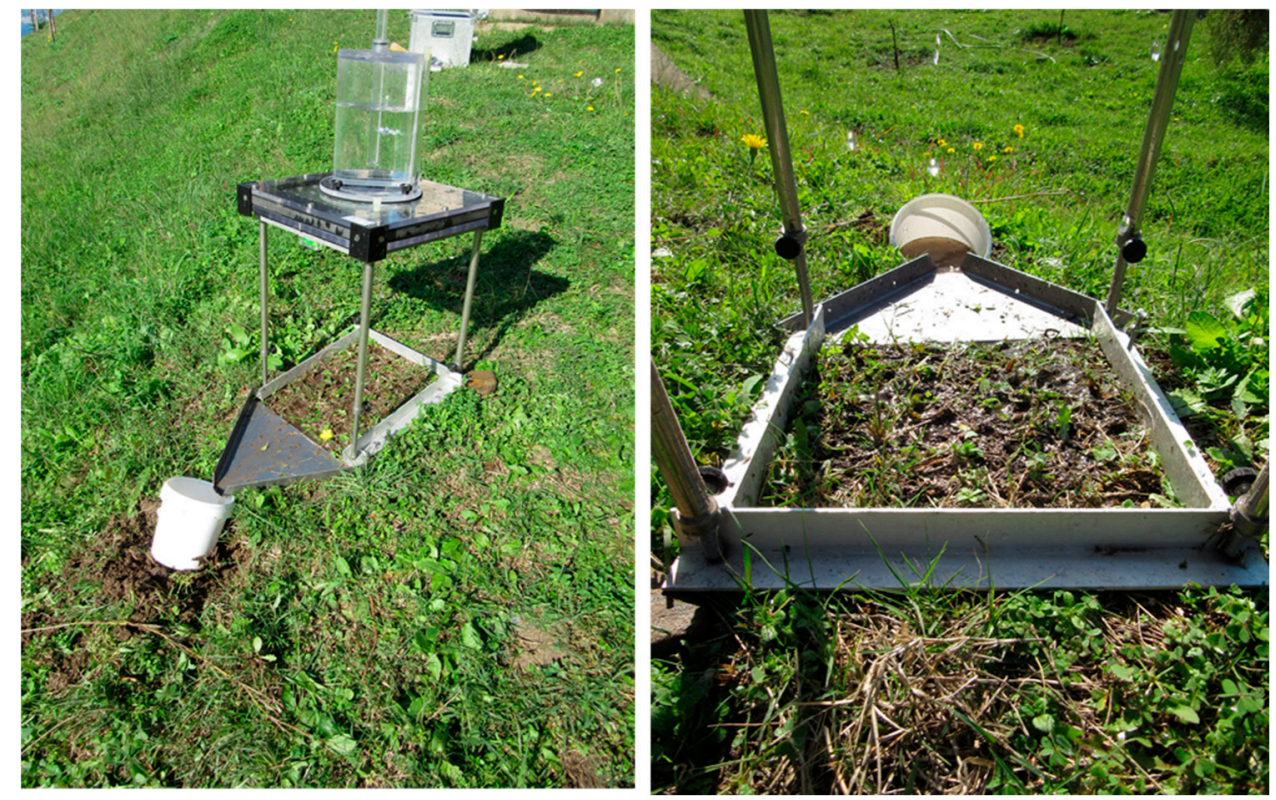

Figure 3. Rain simulator operating in one of the experimental plots (Locri, Southern Italy).

The "disturbed conditions" of soil were generated producing an antecedent rainfall one hour before the IR measurement at the same point. Rainfall that caused disturbed conditions, with the same characteristics of the rainfall simulated during IR measurement, induced soil saturation, which enhances peak runoff generation. Under disturbed conditions, $I R, T_{p}, Q_{p}$ and $S R$ were measured using the same methods as above.

Immediately before the experiments, the vegetation cover of the plots was measured by the grid method $[34,35]$ and the plant species of the plots were classified. One year before the hydrological monitoring of the site, the mean IR of the surface soil was measured using the same rain simulator across 50 points, randomly selected across the eight plots (not yet disturbed by SMPs). The statistical significance of the differences was investigated by applying the Mann-Whitney test (at $p$-level $<0.05$ ) to the hydrological variables measured (SR and IR). The statistical analysis was carried out using XLSTAT release 2017 software (Addinsoft ${ }^{\circledR}$, Paris, France). 


\section{Results}

The mean IR before applying SMPs in the soil, measured one year before the experiment, was $53.9 \pm 3.2 \mathrm{~mm} / \mathrm{h}$. After rainfall simulation, an IR of $15.0 \mathrm{~mm} / \mathrm{h}$ was measured in the control plot ("SP"). Compared to this value, the lowest $(7.8 \mathrm{~mm} / \mathrm{h})$ and highest $(22.1 \mathrm{~mm} / \mathrm{h}) \mathrm{IR}$ values were measured in the plots "MT" (subject to mechanical tillage) and "NTR-1750" (covered by 17.5 tons /ha of vegetal residues), respectively. The plot "NTR-350" (residual biomass of 3.5 tons/ha) showed an IR of $15.0 \mathrm{~mm} / \mathrm{h}$ (Table 1 and Figure 4 ). This suggests that the soils of the various sites do not differ much and it is mainly the SMPs that affected the IRs.

Table 1. Hydrological variables (mean \pm standard deviation) measured in the experimental plots (Locri, Southern Italy) after simulated rainfalls.

\begin{tabular}{|c|c|c|c|c|c|c|c|c|}
\hline \multirow{3}{*}{$\begin{array}{l}\text { Hydrological } \\
\text { Variable }\end{array}$} & \multicolumn{8}{|c|}{ SMP } \\
\hline & \multicolumn{4}{|c|}{ Undisturbed Soil } & \multicolumn{4}{|c|}{ Disturbed Soil } \\
\hline & $S P$ & $M T$ & NTR-350 & NTR-1750 & $S P d$ & MTd & NTR-350d & NTR-1750d \\
\hline $\begin{array}{l}\text { Mean infiltration } \\
\text { rate-IR }(\mathrm{mm} / \mathrm{h})\end{array}$ & $15.0 \pm 1.4^{a}$ & $7.8 \pm 2.1^{b}$ & $15.0 \pm 2.0^{a}$ & $22.1 \pm 2.5^{c}$ & $11.5 \pm 3.2^{A}$ & $2.0 \pm 0.8^{B}$ & $5.6 \pm 2.0^{B}$ & $10.0 \pm 2.2^{A}$ \\
\hline$\underset{(\mathrm{mm} / \mathrm{h})}{\text { Peak runoff- }} Q_{p}$ & $35.0 \pm 4.2^{a}$ & $42.2 \pm 3.2^{b}$ & $40.7 \pm 2.8^{a}$ & $27.1 \pm 2.4^{c}$ & $38.0 \pm 4.5^{A}$ & $48.0 \pm 3.3^{B}$ & $47.0 \pm 3.1^{B}$ & $40.0 \pm 3.8^{A}$ \\
\hline $\begin{array}{c}\text { Time to peak- }-T_{p} \\
\text { (min) }\end{array}$ & $29.0 \pm 3.6^{a}$ & $30.0 \pm 1.4^{a}$ & $30.0 \pm 2.1^{a}$ & $30.0 \pm 2.2^{a}$ & $26.0 \pm 2.6^{A}$ & $24.0 \pm 0.9^{A}$ & $28.0 \pm 3.1^{B}$ & $28.0 \pm 3.0^{B}$ \\
\hline $\begin{array}{c}\text { Surface runoff } \\
\text { volume-SR }(\mathrm{mm})\end{array}$ & $11.5 \pm 2.8^{a}$ & $13.6 \pm 3.2^{b}$ & $11.0 \pm 1.7^{a}$ & $8.0 \pm 1.9^{c}$ & $15.0 \pm 2.8^{A}$ & $16.0 \pm 1.0^{A}$ & $13.3 \pm 2.9^{B}$ & $12.6 \pm 2.7^{B}$ \\
\hline
\end{tabular}

Notes: SMP = Soil Management Practice; SP = Standard Protection of soil; MT = Mechanical Tillage; NTR-350 = No Tillage and Retention of vegetal residues at a dry matter dose of 3.5 tons/ha; NTR-1750 = No Tillage and Retention of vegetal residues at a dry matter dose of 17.5 tons/ha; " $\mathrm{d}$ " indicates that the plot under the SMP was subjected to rainfall disturbance. Significant differences - at $p<0.05$ based on the Mann-Whitney test $(\mathrm{n}=3)$-are indicated by different lowercase (for undisturbed plots) or capital (for disturbed plots) letters among SMPs, and normal or bold characters (between disturbed and undisturbed plots under the same SMP).

In response to the changes in the infiltration rates, the lowest peak runoff $(27.1 \mathrm{~mm} / \mathrm{h})$ was measured in plot "NTR-1750", the one with the highest biomass from pruning residues. Under the remaining SMPs, the measured peak runoff was in the range 35.0 ("SP")-42.2 ("MT") $\mathrm{mm} / \mathrm{h}$. The time to peak was very similar among all the investigated plots (about $30 \mathrm{~min}$ ) (Table 1). Surface runoff generated by plots "NTR-1750" was the lowest $(8.0 \mathrm{~mm})$, while under the other SMPs it ranged from 11.0 ("NTR-350") to 13.6 ("MT") mm.

Soil disturbance by the simulated rainfall (i) reduced "IR" by $23.3 \%$ ("SPd" vs "SP" plots) to $74.4 \%$ ("MTd" vs "MT") with a mean value of 51.4\%; (ii) increased "Q $\mathrm{Q}_{\mathrm{p}}$ " by $8.6 \%$ ("SPd" vs "SP") to 47.6\% ("NTR-1750d" vs "NTR-1750") and on average by 19.3\%; (iii) shifted down T from 29-30 min (undisturbed plots) to 24 ("MTd" plots) - 28 ("NTR-1750d") minutes (on average, $\mathrm{T}_{\mathrm{p}}$ decreased by 10.9\%); (iv) produced higher runoff (+29.0\%) compared to undisturbed plots (Table 1 and Figure 5). 

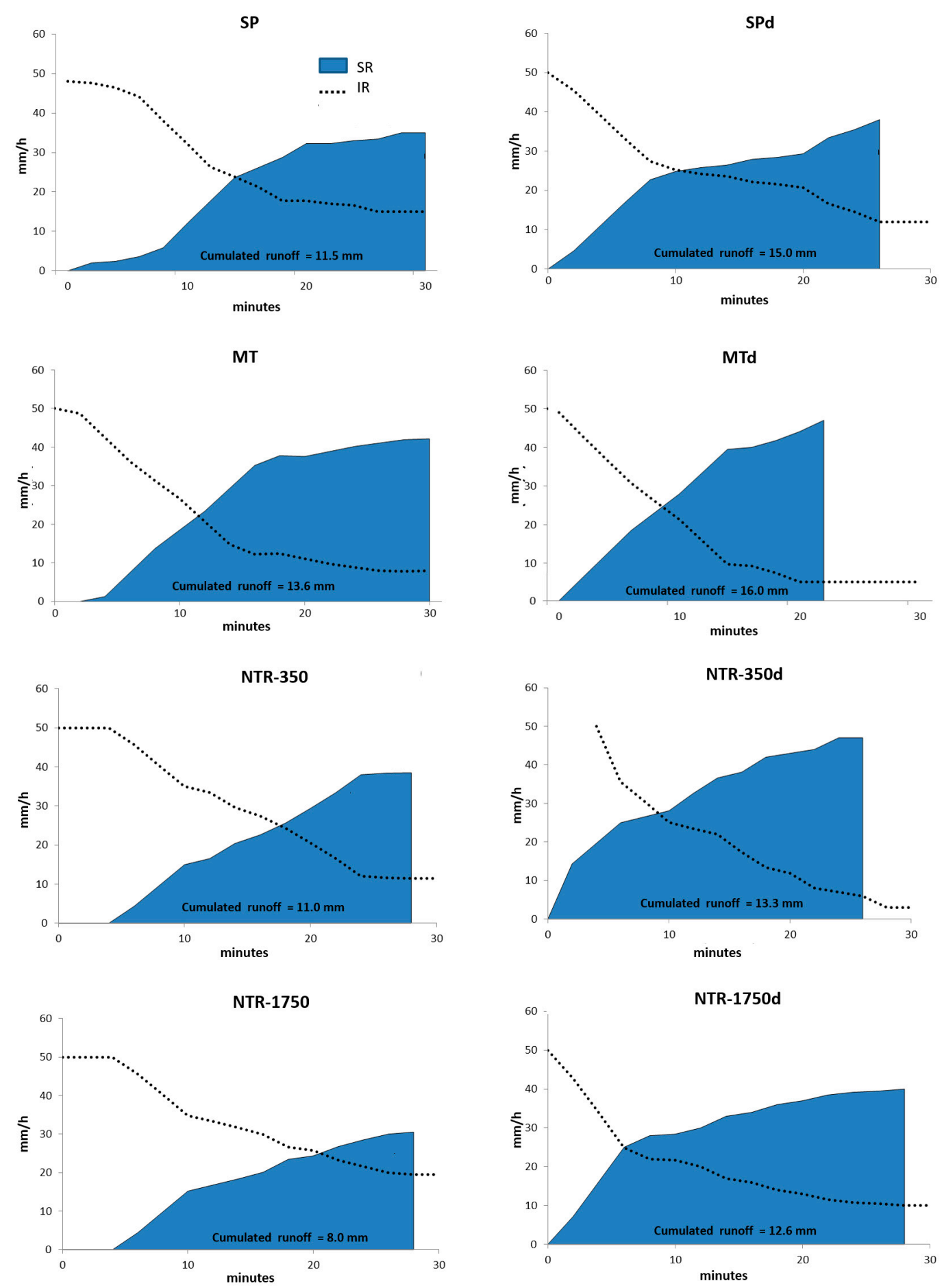

Figure 4. Soil infiltration and surface runoff rates/cumulative runoff volumes (mean of three replicates) measured in the experimental plots (undisturbed and disturbed) after a simulated rainfall of $50 \mathrm{~mm} / \mathrm{h}$ (Locri, Southern Italy). Soil Management Practices (SMP): SP = Standard Protection of soil; MT = Mechanical Tillage; NTR-350 = No Tillage and Retention of vegetal residues at a dry matter dose of 3.5 tons/ha; NTR-1750 = No Tillage and Retention of vegetal residues at a dry matter dose of 17.5 tons/ha); the letter " $\mathrm{d}$ " refers to plots under disturbance conditions due to rainfall simulations; $\mathrm{SR}=$ surface runoff; $\mathrm{IR}=$ infiltration rate. 


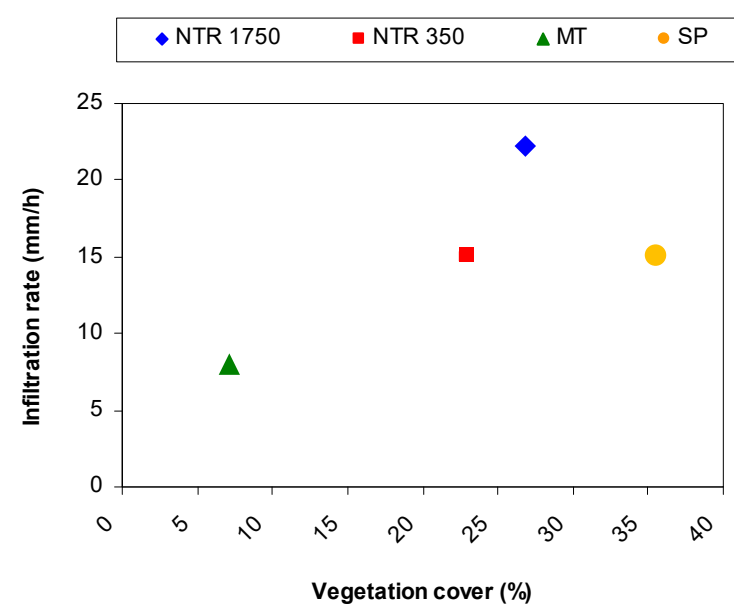

a)

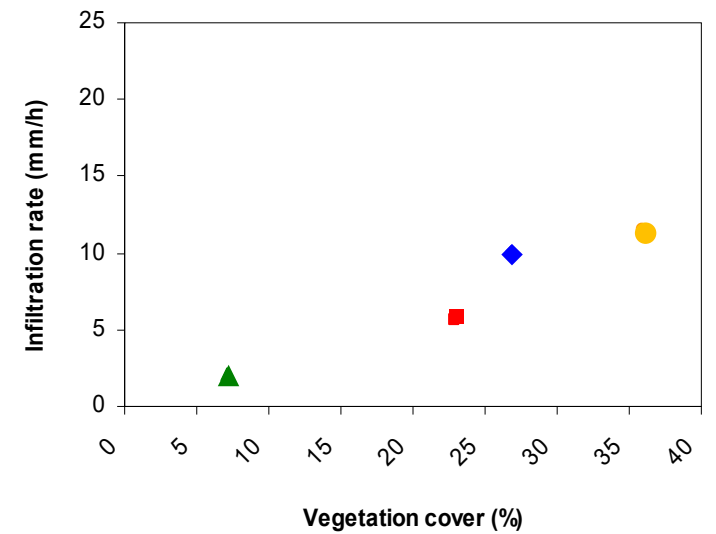

b)

Figure 5. Values of the mean infiltration rates plotted against the vegetation cover measured in the experimental plots. (a), undisturbed plots, and (b), disturbed plots. (Locri, Southern Italy). Soil Management Practices (SMP): SP = Standard Protection of soil; MT = Mechanical Tillage; NTR-350 $=$ No Tillage and Retention of vegetal residues at a dry matter dose of 3.5 tons $/$ ha; NTR-1750 = No Tillage and Retention of vegetal residues at a dry matter dose of 17.5 tons $/$ ha).

\section{Discussions}

The analysis of the hydrological response of the four SMPs highlighted how the common practice locally adopted in the olive groves of Southern Italy (that is, mechanical tillage) led to the highest runoff production among the SMPs experimented in this study. This can have consequent negative effects on soil hydrology, such as intolerable erosion rates with a loss of crop productivity and other off-site environmental effects. Under this management strategy, soil degradation is exacerbated [3].

The experiments clearly show that the soil cover by vegetal residues from pruning (assured by SMPs "NTR-350" and "NTR-1750") reduced the runoff generation capacity of these steep clayey soils (on average by $29 \%$ ), compared to the common practice locally adopted in the farms (SMP "MT"), under both disturbed and undisturbed conditions. This reduction is mainly due to the increased soil infiltration rates (by over 100\%, compared to "MT"). The hydrological response of soil to the experimented SMPs was different between disturbed and undisturbed conditions. More specifically, in the undisturbed soil, the maximum infiltration rate and consequently the minimum runoff was recorded when the soil was treated by the highest dry matter dose ("NTR-1750"); moreover, the hydrological behaviour of plots-for infiltration rates, peak and surface runoff-was significantly different for most of the experimental SMPs $(p<0.05)$. Under "NTR-350" the runoff volume was practically the same as "SP" plots, since the soils had the same mean infiltration rate. Increasing the quantity of vegetal residues even led to half of the runoff volume generated. The other positive effects expected due to the presence of vegetal residues on soil (that is, the reduction of water velocity because of the obstacles to flow over the hillslope) seemed to be minor, as shown by the same $T_{p}$ among the experimental SMPs recorded during the monitoring activity. This suggests that the SMPs were able to reduce the generated runoff, but did not slow down the overland flow velocity on the hillslope.

An important consideration is the relationship between the mean infiltration rate IR and the vegetation cover of plots. In general, the higher the vegetal cover, the higher infiltration rate IR, with the exception of the "SP" plot (Figure 5a). It should be also noticed that the vegetal cover of "MT" plots was much reduced, as an effect of tillage, which may have contributed to the increased runoff generation, the soil being left bare during the precipitation. 
In this study, the lower infiltration rate measured in the plot under "NTR-1750", compared to "NTR-350" plots, can be explained by two factors: (i) the denser cover of coarse residues and vegetation (Figure 5a) dissipating the kinetic energy of precipitation with consequent protection of the soil from sealing; (ii) the great enrichment of the upper soil in organic matter, which, improving the soil structure by increasing the aggregate stability, allowed a higher water infiltration. Therefore, it is evident the role of the vegetal cover in improving the hydrological characteristics of soil, associated with the dissipation of energy from rainfall and runoff and with the increase of infiltration, reduced the sediment transport [36].

These results confirm the general findings of several authors (e.g., [13,37]), who showed that the presence of vegetal residues on soil leads to a considerable increase in infiltration rates compared to conventional farming practices, such as mechanical tillage. For instance, Palese et al. [10] found that in soils of olive groves managed by conservation agriculture principles, water infiltration was enhanced by $15-20 \%$ compared to the conventional system. A 4 -fold infiltration increase below teh tree canopy compared to tilled soil in the lanes of olive groves was noted by [26] and [38], showing the importance of leaving a suitable vegetal cover on the ground. In general, water infiltration improves in areas with vegetal cover compared to conventional tillage and thus runoff coefficients decrease though these changes are highly dependent on soil permeability values [20,21,39].

Other authors highlighted the benefits of maintaining of a proper vegetal cover over soil in terms of reduction of runoff and soil erosion: for instance, in steep almond orchards covered by thyme, barley or lentils [40], in mountainous olive plots with crop cover [41], or in olive orchards covered by seeded homogeneous grass or a mix of different species [9,12].

After soil disturbance, the antecedent rainfall reduced the differences in the hydrological response of soils. Soil infiltration rate and peak runoff were significantly different between mechanical tillage/soil cover at 3.5 tons/ha on the one hand and soils with standard protection and covered by vegetal residues at the highest dose on the other hand. Differences among SMPs were quite small; they were significant only between soil covered by vegetal residues and soils totally protected or mechanically tilled $(p<0.05)$.

The experimental measurements have demonstrated how the runoff generation capacity of a soil disturbed by an antecedent precipitation significantly increases because of the decrease of soil infiltration rates. The soil surface sealing determined by rainfall can explain the reduction of the infiltration rate measured after simulated rainfall [26,42]. Reduced infiltration increases the hydrological risk in particular on less permeable soils. The decrease of water infiltration capacity of soils is of fundamental importance in Mediterranean areas, where the infiltration-excess mechanism dominates runoff generation [43,44]; in such an environmental and climatic context, the intense storm events may increase overland flow $[45,46]$. Given that, retention of vegetal residues to insure mulching of the topsoil even under wet conditions may be advisable to reduce surface runoff generation rates. However, the hydrological effects are not so large as under undisturbed conditions.

The results of the study suggest to farmers that a change in soil management practices should be adopted, in order to exploit the hydrological benefits of vegetal residues retention in the olive-growing region of Southern Italy rather than applying traditional practices based on mechanical tillage. With regards to the Calabria region, the annual production of pruning residues is 1.0 to 3.0 tons per hectare [47]; usually, the pruning residues are burned or disposed in landfills. The study has demonstrated that a dose of 3.5 tons/ha noticeably increased soil infiltration and thus improved its hydrological response. This increase in infiltration might translate into a reduction of runoff rates for usual events. Moreover, the re-use of these residues avoids their burning in the farms (requiring a large amount of the labour force), with the possible risk of fires in olive trees, increase in $\mathrm{CO}_{2}$ emissions and reduction in $C$ sequestration $[13,48,49]$. Therefore, the placement over the soil of the pruning residues annually produced by an olive grove could be enough to achieve a good soil protection effect against runoff and erosion risks. A 5-fold dose (17.5 tons/ha) would further improve the hydrological behaviour of soil, but it would require supplying pruning residues from other places 
with high transport costs (often not sustainable by local farmers). This higher dose might also suggest the maximum benefit that can be obtained in the case that the farmers decided to concentrate pruning residues in specific areas of the orchard, for instance, adding the residues in alternative lanes or combining the pruning of two-tree lines into the common lane.

\section{Conclusions}

This study has evaluated the hydrological response of steep and clayey soils in Mediterranean olive groves subjected to four soil management practices (also under the disturbance of intense rainfall). The measurements of infiltration and surface runoff using a rainfall simulator on selected plots showed that mechanical tillage commonly adopted in the olive groves of Southern Italy leads to low values of soil infiltration and high runoff production. Instead, the retention of a soil cover by vegetal residues (3.5-17.5 tons/ha of dry matter) reduces the runoff generation capacity on average by $30 \%$, mainly because of the increased soil infiltration rates (over 100\%, compared to mechanical tillage).

After soil disturbance due to antecedent rainfall, the runoff generation capacity of a soil disturbed by a heavy precipitation significantly worsens compared to undisturbed soils because of the decrease of soil infiltration rates. Under these conditions, the hydrological response of soils under different management practices is less pronounced than in undisturbed soils due to generalized soil surface sealing determined by rainfall. The retention of vegetal residues over saturated soil immediately after rainfall may be advisable to reduce surface runoff generation rates. However, the hydrological effects are not as pronounced as under undisturbed conditions, since the differences in runoff volume between soils covered by vegetal residues and tilled soils are lower than under undisturbed conditions.

Taking into account our results and those from the available literature, the use of conservation agriculture management systems should be strongly encouraged by agricultural policy strategies for the related agronomic and environmental benefits. Strong expertise are needed to apply these practices in a correct way (in particular, cover crop and biomass retention) and to convince olive farmers to adopt them.

Author Contributions: The authors contributed with equal effort to the realization of the study.

Funding: This research was funded by the Italian research project PON “Modelli Sostenibili e Nuove tecnologie per la Valorizzazione delle Olive e dell'Olio Extravergine di Oliva Prodotto in Calabria". Grant no. PON03 PE 00090_2.

Acknowledgments: The funders had no role in the design of the study; in the collection, analyses, or interpretation of data; in the writing of the manuscript, or in the decision to publish the results.

Conflicts of Interest: The authors declare no conflict of interest.

\section{References}

1. Álvarez, S.; Soriano, M.A.; Landa, B.B.; Gómez, J.A. Soil properties in olive groves compared with that in natural areas in a mountainous landscape in southern Spain. Soil Use Manag. 2007, 23, 404-416. [CrossRef]

2. Beaufoy, G. UE Policies for Olive Farming-Unsustainable on All Counts; WWF's European Policy Office-Birdlife International: Brussels, Belgium, 2001; Available online: http:/ /www.wwf.org.uk/filelibrary/pdf/oliveoli. odf (accessed on 30 November 2018).

3. Gómez, J.A.; Infante-Amate, J.; González de Molina, M.; Vanwalleghem, T.; Taguas, E.V.; Lorite, I. Olive cultivation, its impact on soil erosion and its progression into yield impacts in southern Spain in the past as a key to a future of increasing climate uncertainty. Agriculture 2014, 4, 170-198. [CrossRef]

4. Gómez, J.A.; Rodríguez-Carretero, M.T.; Lorite, I.J.; Fereres, E. Modeling to evaluate and manage climate change effects on water use in Mediterranean olive orchards with respect to cover crops and tillage management. In Advances in Agricultural Systems Modeling; Practical Applications of Agricultural System Models to Optimize the Use of Limited Water; Ahuja, L.R., Ma, L., Lascano, R.J., Eds.; ASA/CSSA/SSSA: Madison, WI, USA, 2014; Volume 5, pp. 237-265. [CrossRef] 
5. Calvo-Cases, A.; Boix-Fayos, C.; Imeson, A.C. Runoff generation, sediment movement and soil water behaviour on calcareous (limestone) slopes of some Mediterranean environments in southeast Spain. Geomorphology 2003, 50, 269-291. [CrossRef]

6. Beaufoy, G. The Environmental Impact of the Olive Oil Production in the European Union: Practical Options for Improving the Environmental Impact. 2002. Available online: http:/ / www.ec.europa.eu/environment/ agriculture/pdf/oliveoil.pdf (accessed on 11 November 2018).

7. Xiloyannis, C.; Martinez Raya, A.; Kosmas, C.; Favia, M. Semi-intensive olive orchards on sloping land: Requiring good land husbandry for future development. J. Environ. Manag. 2008, 89, 110-119. [CrossRef] [PubMed]

8. Gómez, J.A. Sustainability using cover crops in Mediterranean tree crops, olives and vines: Challenges and current knowledge. Hung. Geogr. Bull. 2017, 66. [CrossRef]

9. Gómez, J.A.; Campos, M.; Guzmán, G.; Castillo-Llanque, F.; Van walleghem, T.; Lora, A.; Giráldez, J.V. Soil erosion control, plant diversity, and arthropod communities under heterogeneous cover crops in an olive orchard. Environ. Sci. Pollut. Res. 2018, 25, 977-989. [CrossRef] [PubMed]

10. Palese, A.M.; Vignozzi, N.; Celano, G.; Agnelli, A.E.; Pagliai, M.; Xiloyannis, C. Influence of soil management on soil physical characteristics and water storage in a mature rainfed olive orchard. Soil Tillage Res. 2014, 144, 96-109. [CrossRef]

11. Viola, F.; Caracciolo, D.; Pumo, D.; Noto, L.V.; Loggia, G.L. Future climate forcings and olive yield in a Mediterranean orchard. Water 2014, 6, 1562-1580. [CrossRef]

12. Gómez, J.A.; Llewellyn, C.; Basch, G.; Sutton, P.B.; Dyson, J.S.; Jones, C.A. The effects of cover crops and conventional tillage on soil and runoff loss in vineyards and olive groves in several Mediterranean countries. Soil Use Manag. 2011, 27, 502-514. [CrossRef]

13. Repullo, M.A.; Carbonell, R.; Hidalgo, J.; Rodriguez-Lizana, A.; Ordonez, R. Using olive pruning residues to cover soil and improve fertility. Soil Tillage Res. 2012, 124, 36-46. [CrossRef]

14. Ben-Salem, N.; Álvarez, S.; López-Vicente, M. Soil and water conservation in rainfed vineyards with common sainfoin and spontaneous vegetation under different ground conditions. Water 2018, 10, 1058. [CrossRef]

15. Francia, J.R.; Martinez, A.; Ruiz, S. Erosion en suelos de olivar en Fuertes pendientes. Comportamientos de distintos manejos de suelo (Soil erosion in olive groove on steep slopes. Behaviors of different soil management). Edafologia 2000, 7, 147-155.

16. Ordoñez, R.; Rodriguez-Lizana, A.; Espejo-Perez, A.; Gonzalez, P.; Saavedra, M. Soil and available phosphorus losses in ecological olive groves. Eur. J. Agron. 2007, 27, 144-153. [CrossRef]

17. Snelder, D.J.; Bryan, R.B. The use of rainfall simulation tests to assess the influence of vegetation density on soil loss on degraded rangelands in the Baringo District, Kenya. Catena 1995, 25, 105-116. [CrossRef]

18. Monteiro, A.; Lopes, C.M. Influence on cover crop on water use and performance of vineyard in Mediterranean Portugal. Agric. Ecosyst. Environ. 2007, 121, 336-342. [CrossRef]

19. Francia-Martinez, J.R.; Duran, V.H.; Martinez-Raya, A. Environmental impact from mountainous olive orchards under different soil-management systems (SE Spain). Sci. Total Environ. 2006, 358, 46-60. [CrossRef]

20. López-Vicente, M.; García-Ruiz, R.G.; Guzmán, G.; Vicente-Vicente, J.L.; VanWesemael, B.; Gómez, J.A. Temporal stability and patterns of runoff and runon with different cover crops in an olive orchard (SW Andalusia, Spain). Catena 2016, 147, 125-137. [CrossRef]

21. Gomez, J.A.; Sobrinho, T.A.; Giraldez, J.V.; Fereres, E. Soil management effects on runoff, erosion and soil properties in an olive grove of southern Spain. Soil Tillage Res. 2009, 102, 5-13. [CrossRef]

22. Soriano, M.A.; Álvarez, S.; Landa, B.B.; Gómez, J.A. Soil properties in organic olive orchards following different weed management in a rolling landscape of Andalusia, Spain. Renew. Agric. Food Syst. 2014, 29, 83-91. [CrossRef]

23. Milgroom, J.; Soriano, M.A.; Garrido, J.M.; Gómez, J.A.; Fereres, E. The influence of a shift from conventional to organic olive farming on soil management and erosion risk in southern Spain. Renew. Agric. Food Syst. 2007, 22, 1-10. [CrossRef]

24. Soria, L.; Fernández, E.; Pastor, M.; Aguilar, J.; Muñoz, J.A. Impact of olive-orchard cropping system on some physical and chemical properties in Southern Spain. Adv. Geoecol. 2005, 36, 428-435. 
25. Hernández, A.J.; Lacasta, C.; Pastor, J. Effects of different soil management practices on soil conservation and soil water in a rainfed olive orchard. Agric. Water Manag. 2005, 77, 232-248. [CrossRef]

26. Gòmez, J.A.; Giràldez, J.V.; Fereres, E. Effects of tillage method on soil physical properties, infiltration and yield in an olive orchard. Soil Tillage Res. 1999, 52, 167-175. [CrossRef]

27. Vanderlinden, K.; Gabriels, D.; Giráldez, J.V. Evaluation of infiltration measurements under olive trees in Córdoba. Soil Tillage Res. 1998, 48, 303-315. [CrossRef]

28. Velázquez-Martí, B.; Fernández-González, E.; López-Cortés, I.; Salazar-Hernández, D.M. Quantification of the residual biomass obtained from pruning of trees in Mediterranean olive groves. Biomass Bioenergy 2011, 35, 3208-3217. [CrossRef]

29. Gómez, J.A.; Francia, J.R.; Guzmán, G.; Vanwalleghem, T.; Durán Zuazo, V.H.; Castillo, C.; Barrón, V. Lateral transfer of organic carbon and phosphorus by water erosion at hillslope scale in southern Spain olive orchards. Vadose Zone J. 2017, 16. [CrossRef]

30. Kottek, M.; Grieser, J.; Beck, C.; Rudolf, B.; Rubel, F. World Map of the Köppen-Geiger climate classification updated. Meteorol. Z. 2006, 15, 259-263. [CrossRef]

31. Food and Agriculture Organization of the United Nations. World Reference Base for Soil Resources 2006; World Soil Recourses Reports No. 103; Food and Agriculture Organization of the United Nations: Rome, Italy, 2006.

32. Iserloh, T.; Ries, J.B.; Arnáez, J.; Boix-Fayos, C.; Butzen, V.; Cerdà, A.; Echeverría, M.T.; Fernández-Gálvez, J.; Fister, W.; Geißler, C.; et al. European small portable rainfall simulators: A comparison of rainfall characteristics. Catena 2013, 110, 100-112. [CrossRef]

33. Hlavčová, K.; Danáčová, M.; Kohnová, S.; Szolgay, J.; Valent, P.; Výleta, R. Estimating the effectiveness of crop management on reducing flood risk and sediment transport on hilly agricultural land-A Myjava case study, Slovakia. Catena 2019, 172, 678-690. [CrossRef]

34. Vogel, K.P.; Masters, R.A. Frequency grid: A simple tool for measuring grassland establishment. J. Range Manag. 2001, 54, 653-655. [CrossRef]

35. Bombino, G.; Gurnell, A.M.; Tamburino, V.; Zema, D.A.; Zimbone, S.M. A method for assessing channelization effects on riparian vegetation in a Mediterranean environment. River Res. Appl. 2007, 23, 613-630. [CrossRef]

36. Taguas, E.V.; Arroyo, C.; Lora, A.; Guzmán, G.; Vanderlinden, K.; Gómez, J.A. Exploring the linkage between spontaneous grass cover biodiversity and soil degradation in two olive orchard microcatchments with contrasting environmental and management conditions. Soil 2015, 1, 651-664. [CrossRef]

37. Bissett, M.J.; O'Leary, G.J. Effects of conservation tillage and rotation on water infiltration in two soils in south-eastern Australia. Aust. J. Soil Res. 1996, 3, 299-308. [CrossRef]

38. Guzmán, G.; Vanderlinden, K.; Giráldez, J.V.; Gómez, J.A. Assessment of spatial variability in water erosion rates in an olive orchard at plot scale using a magnetic iron oxide tracer. Soil Sci. Soc. Am. J. 2013, 77, 350-361. [CrossRef]

39. Taguas, E.V.; Peña, A.; Ayuso, J.L.; Pérez, R.; Yuan, Y.; Giráldez, J.V. Rainfall variability and hydrological and erosive response of an olive tree microcatchment under no-tillage with a spontaneous grass cover in Spain. Earth Surf. Process. Landf. 2010, 35, 750-760. [CrossRef]

40. Martinez Raya, A.; Duran Zuazo, V.H.; Francia Marinez, J. Soil erosion and runoff response to plant-cover strips on semiarid slope (SE Spain). Land Degrad. Dev. 2006, 17, 1-11. [CrossRef]

41. Duran-Zuazo, V.H.; Pleguezuelo, C.R.; Panadero, L.A.; Raya, A.M.; Martinez, J.F.; Rodriguez, B.C. Soil conservation measures in rainfed olive orchards in south-eastern Spain: Impacts of plant strips on soil water dynamics. Pedosphere 2009, 19, 453-464. [CrossRef]

42. Helalia, A.M.; Letey, G.J.; Graham, R.C. Crust formation and clay migration effects on infiltration rate. Soil Sci. Soc. Am. J. 1988, 52, 251-255. [CrossRef]

43. Hillel, D. Environmental Soil Physics: Fundamentals, Applications, and Environmental Considerations; Elsevier: Amsterdam, The Nederland, 1998.

44. Shakesby, R.A. Post-wildfire soil erosion in the Mediterranean: Review and future research directions. Earth-Sci. Rev. 2011, 105, 71-100. [CrossRef]

45. Fortugno, D.; Boix-Fayos, C.; Bombino, G.; Denisi, P.; Quiñonero Rubio, J.M.; Tamburino, V.; Zema, D.A. Adjustments in channel morphology due to land-use changes and check dam installation in mountain torrents of Calabria (southern Italy). Earth Surf. Processes Landf. 2017, 42, 2469-2483. [CrossRef] 
46. Lucas-Borja, M.E.; Zema, D.A.; Carrà, B.G.; Cerdà, A.; Plaza-Alvarez, P.A.; Cózar, J.S.; de las Heras, J. Short-term changes in infiltration between straw mulched and non-mulched soils after wildfire in Mediterranean forest ecosystems. Ecol. Eng. 2018, 122, 27-31. [CrossRef]

47. Di Blasi, C.; Tanzi, V.; Lanzetta, M. A study on the production of agricultural residues in Italy. Biomass Bioenergy 1997, 12, 321-333. [CrossRef]

48. Qingren, W.; Yuncong, L.; Ashok, A. Cropping systems to improve carbon sequestration for mitigation of climate change. J. Environ. Prot. 2010, 1, 207-215. [CrossRef]

49. Taguas, E.V.; Ayuso, J.L.; Pérez, R.; Giráldez, J.V.; Gómez, J.A. Intra and inter-annual variability of runoff and sediment yield of an olive micro-catchment with soil protection by natural ground cover in Southern Spain. Geoderma 2013, 206, 49-62. [CrossRef]

(C) 2019 by the authors. Licensee MDPI, Basel, Switzerland. This article is an open access article distributed under the terms and conditions of the Creative Commons Attribution (CC BY) license (http:/ / creativecommons.org/licenses/by/4.0/). 